Edubiotik: Jurnal Pendidikan, Biologi dan Terapan

ISSN 2528-679X (print), ISSN 2597-9833 (online)

Volume 4, Nomor 02, Tahun 2019, Hal. 110 - 120

Available online at:

http://ejurnal.budiutomomalang.ac.id/index.php/edubiotik

\title{
Analisis mutu briket arang dari limbah biomassa campuran kulit kopi dan tempurung kelapa dengan perekat tepung tapioka
}

\author{
Bagus Setyawan, Rosiana Ulfa \\ Program Studi Teknologi Hasil Pertanian, Universitas PGRI Banyuwangi, Banyuwangi, Indonesia \\ E-mail: bagusetyawan89@gmail.com*, roshi_n2002@yahoo.com
}

\begin{tabular}{ll}
\hline Informasi Artikel & \multicolumn{1}{c}{ ABSTRACT } \\
\hline Submit: & Plantation wastes such as coffee skins and coconut shells in Indonesia have \\
$02-08-2019$ & not been utilized optimally. Waste can be utilized for the manufacture of \\
Diterima: & charcoal briquettes as an alternative fuel. The purpose of this study was to \\
$21-08-2019$ & determine the quality of charcoal briquettes from biomass waste mixed with \\
Dipublikasikan: & coffee skin and coconut shell with tapioca flour adhesive. This research is a \\
$01-09-2019$ & type of laboratory experimental research. The study used a Completely \\
& Randomized Design (CRD) with 3 replications. Testing the quality of charcoal \\
& briquettes includes tests of water content, ash content, combustion rate, and \\
& heating value. The research data will be compared with the International \\
& charcoal briquette quality standards and the Indonesian National Standard \\
& (INS). The results showed that the water content and an ash content of the \\
& charcoal briquettes were still below the international charcoal briquette quality \\
& standards and INS. However, the heating value of this charcoal briquette is \\
& surpass the SNI quality standard. The conclusion of the research is the quality \\
& of the charcoal briquettes from the waste of biomass of coffee husk and \\
& coconut shell with tapioca flour recorder in the aspects of water content and \\
& ash content is still below the international quality standard and INS, but in the \\
& aspect of the heat value of the charcoal briquette the research results are \\
above the SNI quality standard. & \\
Key words: Charcoal briquettes, Coconut shell, Coffee skins
\end{tabular}

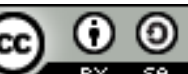

This Edubiotik : Jurnal Pendidikan, Biologi dan Terapan is licensed under a CC BY-SA (Creative Commons Attribution-ShareAlike 4.0 International License) 


\section{PENDAHULUAN}

Sektor pertanian di Indonesia merupakan sektor yang terbesar dan menjadi tumpuan perekonomian bangsa dimana potensi sumber daya alam Indonesia sangat kaya dari ujung barat hingga ujung timur. Kekayaan sumber daya alam Indonesia ini dimanfaatkan oleh sebagian besar masyarakat Indonesia untuk menjadi penopang hidup. Banyak usaha rakyat mulai dari skala yang paling kecil hingga perusahaan besar bertaraf internasional tumbuh dari sektor pertanian. Hampir sebagian besar industri-industri yang ada di Indonesia masih menggunakan bahan bakar fosil sebagai bahan bakar utama, dimana bahan bakar fosil merupakan bahan bakar yang tidak terbaharukan dan jumlahnya semakin lama semakin menipis menuju kepunahan (Prastowo, 2015).

Energi bahan bakar tidak terbaharukan yang semakin lama semakin habis menjadi perhatian banyak kalangan dan mulai banyak praktisi maupun akademisi mulai mencoba membuat bahan bakar alternatif yang berasal dari sumber daya yang terbaharukan. Hal ini menjadi penting dilakukan untuk mengurangi ketergantungan terhdap bahan bakar fosil. Salah satu bahan bakar alternatif yang mulai banyak diproduksi adalah pembuatan briket. Briket merupakan sebuah blok yang digunakan sebagai bahan bakar untuk membuat api. Selama ini briket yang digunakan sebagian besar masih berasal dari batubara dan sumber daya alam ini akan semakin habis jika terus dieksploitasi. Maka dari itu perlu adanya alternatif lain pembuatan briket yang berbahan dasar dari sumber daya yang terbaharukan yaitu pembuatan briket arang dari limbah biomassa (Fairus, et all, 2011).

Biomassa adalah komposisi bahan organik yang komplek yang terdiri dari karbohidrat, lemak, protein, dan mineral lain seperti sodium, fosfor, kalsium, dan besi (Pari dan Abdurrohim, 2003). Sedangkan komponen utama biomassa terdiri dari selulosa dan lignin (Arni, et all, 2014). Penggunaan limbah biomassa merupakan salah satu alternatif yang bisa dilakukan mengingat potensi sektor pertanian yang sangat kaya sekali di Indonsia dan limbah biomassa yang dihasilkan pun juga sangat melimpah. Limbah biomassa umumnya terdiri dari limbah padat, limbah cair, dan limbah gas. Tetapi pada umumnya limbah biomassa yang banyak digunakan sebagai bahan bakar briket adalah limbah biomassa padat, misalnya sekam padi, sekam kopi, tempurung kelapa, serbuk kayu, dan banyak lagi limbah biomassa lainnya (Gustan Pari, 2012).

Penelitian yang bertujuan untuk memanfaatkan limbah biomassa menjadi briket pun juga mulai dilakukan. Hasil penelitian Qistina, et all (2016), yang meneliti kajian kualitas briket biomassa dari sekam padi dan tempurung kelapa menyimpulkan bahwa briket biomassa yang dihasilkan mempunyai kualitas yang cukup baik dan bisa dijadikan energi alternatif. Putri dan Andasuryani (2017), yang melakukan penelitian tentang mutu briket arang dengan bahan baku limbah biomassa juga menyimpulkan bahwa kualitas briket dari bahan dasar tempurung kelapa memiliki mutu yang cukup baik. Penelitian lain tentang pemanfaatan kulit kopi menjadi biobriket menghasilkan kesimpulan bahwa briket dari kulit kopi layak menjadi energi alternatif yang baru dengan kualitas yang cukup baik (Sariadi, 2016). Selain itu masih banyak dilakukan penelitian tentang pembuatan briket dari biomassa. 
Penelitian ini menggunakan campuran kulit kopi dan tempurung kelapa sebagai bahan baku pembuatan briket arang biomassa. Alasan penggunaan kulit kopi dan tempurung kelapa karena berdasarkan penelitian yang sudah dilakukan kedua limbah biomassa tersebut layak untuk dimanfatkan sebagai bahan pembuatan briket arang. Selain itu penelitian ini dilakukan di Banyuwangi dimana Banyuwangi merupakan sentra produksi kelapa dan kopi terbesar di Jawa timur. Berdasarkan data dari Badan Pusat Statistik tahun 2017 produksi kopi di Banyuwangi sebesar 13.839 ton, sedangkan produksi kelapa tahun 2018 di Banyuwangi sebesar 33.945 ton (BPS, 2018).

Pembuatan briket arang dari limbah biomassa campuran kulit kopi dan tempurung kelapa ini akan dilakukan proses karbonasi atau pengarangan terlebih dahulu untuk mendapatkan arang yang nantinya dihaluskan menjadi serbuk arang dan ditambahkan tepung tapioka (kanji) sebagai bahan perekatnya. Pemilihan kanji sebagai bahan perekat karena dari sekian banyak bahan perekat kanji adalah salah satu perekat yang baik untuk campuran briket (Patandung, 2017; Faizal et all, 2014). Selanjutnya campuran arang biomassa yang sudah ditambahkan tepung tapioka sebagai perekat dicetak dalam cetakan briket untuk selanjutnya dilakukan uji kualitas briket meliputi kadar air, kadar abu, laju pembakaran, serta nilai kalornya.

Produksi kulit kopi dan kelapa yang besar di wilayah Banyuwangi tentunya menghasilkan limbah kulit kopi dan tempurung kelapa yang melimpah. Hal ini menjadi salah satu peluang pengembangan pembuatan briket arang dari limbah biomassa kedua bahan tersebut. Oleh karena itu perlu dilakukan penelitian tentang pembuatan briket arang berbahan dasar limbah biomassa campuran kulit kopi dan tempurung kelapa dengan menggunakan perekat tepung tapioka (kanji) yang merupakan salah satu komoditas unggulan di Banyuwangi yang sekaligus juga belum pernah dilakukan penelitian sebelumnya tentang pembuatan briket arang dari limbah biomassa campuran kulit kopi dan tempurung kelapa serta tepung tapioka sebagai perekat. Dengan demikian, penelitian ini bertujuan untuk mengetahui kualitas briket biomassa campuran kulit kopi dan tempurung kelapa dengan dengan perekat menggunakan tepung tapioka.

\section{METODE PENELITIAN}

Penelitian pembuatan briket arang biomassa dari campuran kulit kopi dan tempurung kelapa ini merupakan jenis penelitian kuantitatif. Penelitian ini dilakukan secara faktorial dengan menggunakan rancangan acak lengkap (RAL) dengan 3 kali ulangan. Faktor perbandingan komposisi kulit kopi (TK) dan tempurung kelapa (KK) telah ditentukan dengan komposisi: L1 (KK : TK = 75\%:25\%); L2 (KK : TK $=25 \%$ : 75\%); L3 (KK : TK $=50 \%: 50 \%$ ). Sedangkan konsentrasi tepung tapioka sebagai perekat digunakan konsentrasi $5 \%$ dari berat adonan briket. Penelitian ini dilakukan dalam jangka waktu kurang lebih tiga (3) bulan mulai dari bulan Mei s.d Juni 2019. Lokasi penelitian pembuatan briket arang dari limbah biomassa biomassa ini dilakukan di Banyuwangi dengan bahan baku tempurung kelapa didapatkan dari Desa Wonosobo, Kalipuro, Muncar, dan Banyuwangi. Sedangkan kulit kopi didapatkan dari Perkebunan Kali Selogiri yang berada di Kecamatan Kalipuro. 
Bahan yang digunakan dalam penelitian ini adalah limbah biomassa yakni kulit kopi, tempurung kelapa, air, dan tapioka (kanji). Alat yang digunakan adalah timbangan digital, tumbukan, ayakan ukuran 100 mesh, alat cetak briket, oven, jangka sorong, tungku pembakaran, cawan, alat tulis, dan bomb calorimeter untuk uji nilai kalor. Penelitian dimulai dengan mengeringkan kulit kopi dan tempurung kelapa dengan dijemur panas matahari, kemudian limbah biomassa dimasukkan kedalam tungku pembakaran dan dikarbonasi di atas api sampai membentuk arang. Arang limbah biomassa yang telah terbentuk dihaluskan dengan tumbukan sampai membentuk pasir arang. Pasir briket tersebut ditambahkan tapioka dengan jumlah $5 \%$ dari total adonan dan ditambahkan air untuk selanjutnya dipress dengan alat cetak briket sehingga menghasilkan briket arang biomassa. Data penelitian meliputi; kadar air, kadar abu, laju pembakaran, dan nilai kalor. Kadar air, kadar abu, dan laju pembakaran, dan nilai kalor diperoleh dengan rumus sebagai berikut (Rindayatno dan Lewar, 2017).

$$
\begin{gathered}
\text { Kadar air }=\frac{\mathrm{B}-\mathrm{C}}{\mathrm{B}-\mathrm{A}} \times 100 \% \\
\text { Kadar abu }=\frac{\mathrm{C}-\mathrm{A}}{\mathrm{B}} \times 100 \% \\
\text { Laju pembakaran }=\frac{\mathrm{M}}{\mathrm{W}} \\
\text { Nilai Kalor }=\frac{(\mathrm{T} 2-\mathrm{T} 1) \times \mathrm{CV}}{\mathrm{M}}
\end{gathered}
$$

Keterangan:

$$
\begin{array}{ll}
\mathrm{A} & =\text { massa cawan kosong }(\mathrm{gr}) \\
\mathrm{B} & =\text { massa cawan }+ \text { sampel }(\mathrm{gr}) \\
\mathrm{C} & =\text { massa cawan }+ \text { sampel setelah dioven }(\mathrm{gr}) \\
\mathrm{M} & =\text { Massa briket }(\mathrm{gr}) \\
\mathrm{W} & =\text { Waktu pembakaran briket }(\mathrm{s}) \\
\mathrm{T} 2 & =\text { Suhu setelah pengeboman }\left({ }^{\circ} \mathrm{C}\right) \\
\mathrm{T} 1 & =\text { Suhu sebelum pengeboman }\left({ }^{\circ} \mathrm{C}\right) \\
\mathrm{CV} & =\text { Panas jenis bomb calorimeter }\left(73529,6 \text { joule } / \mathrm{g}^{\circ} \mathrm{C}\right)
\end{array}
$$

Analisis data penelitian dengan membandingkan data yang telah diperoleh dengan standart mutu briket arang Internasional dan Standart Nasional Indonesia (SNI).

\section{HASIL PENELITIAN DAN PEMBAHASAN}

Penelitian tentang analisis kualitas briket arang biomassa campuran limbah kulit kopi dan tempurung kelapa dengan perekat tepung tapioka ini dilakukan dengan membuat tiga sampel berdasarkan komposisi bahan bakunya. Analisis uji kualitas yang dilakukan meliputi; kadar air, kadar abu, laju pembakaran, dan nilai kalor briket yang dihasilkan. Data hasil penelitian yang didapatkan dianalisis kemudian dilihat 
apakah briket arang dari limbah biomassa campuran kulit kopi dan tempurungkelapa dengan perekat tepung tapioka ini memiliki kualitas yang baik dan layak untuk diproduksi atau tidak. Pengambilan keputusan ini didasarkan pada standart baku mutu briket arang baik dari Amerika, Jepang, dan Indonesia.

\section{Analisis kadar air}

Hasil analisis kadar air pada briket arang dari limbah biomassa campuran kulit kopi dan tempurung kelapa dengan perekat tepung tapioka ditunjukkan oleh Tabel 1.

Tabel 1. Hasil Analisis Kadar Air pada Briket Arang Limbah Biomassa Campuran Kulit Kopi dan Tempurung Kelapa Dengan Perekat Tepung Tapioka

\begin{tabular}{cccccc}
\hline Komposisi & Kadar Air & \multicolumn{4}{c}{ Standar Baku Mutu } \\
\cline { 3 - 6 } KK $:$ TK $=75 \%: 25 \%$ & $13,872 \%$ & $6-8 \%$ & $3,6 \%$ & $6,2 \%$ & $8 \%$ \\
KK $:$ TK $=25 \%: 75 \%$ & $14,966 \%$ & & & & \\
KK $:$ TK $=50 \%: 50 \%$ & $12,487 \%$ & & & & \\
\hline
\end{tabular}

Berdasarkan Tabel 1 tentang hasil analisis kadar air pada briket arang limbah biomassa campuran kulit kopi dan tempurung kelapa dapat dilihat bahwa rata-rata kadar air ketiga sampel briket tergolong tinggi yakni berkisar antara 12\% - 14\%. Kadar air terkecil terdapat pada briket arang dengan campuran kulit kopi dan tempurung kelapa masing-masing 50\% yakni sebesar $12,487 \%$. Sedangkan kadar air tertinggi terdapat pada briket arang dengan campuran tempurung kelapa $75 \%$ sebesar $14,966 \%$. Kadar air briket berpengaruh terhadap nilai kalor. Semakin kecil kadar air maka nilai kalornya akan semakin baik, dan sebaliknya. Tempurung kelapa memiliki kadar air yang lebih tinggi daripada kulit kopi sehingga kadar air dalam briket arang yang memiliki kandungan tempurung kelapa yang tinggi cenderung tinggi. Selain itu kadar air yang lebih tinggi ini disebabkan tempurung kelapa memiliki jumlah pori-pori yang lebih banyak dan nantinya berpengaruh juga terhadap susah tidaknya briket arang ketika dinyalakan pada awal pembakaran (Maryono et all, 2013). Faktor yang lain karena lama waktu karbonasi tempurung kelapa lebih lama dibandingkan kulit kopi, sehingga ketika temperatur pada waktu karbonasi kurang tinggi dan waktu karbonasi kurang lama maka proses karbonasi tempurung kelapa kurang maksimal dan menyebabkan kadar airnya masih tinggi . Berdasarkan tabel data hasil penelitian diketahui bahwa nilai kadar air pada ketiga sampel rata-rata masih diatas standart kadar air dari briket arang buatan Jepang, Inggris, Amerika, dan Indonesia. Kadar air briket arang pada penelitian ini masih mendekati SNI sehingga dengan metode pembuatan dan perlakuan yang lebih baik briket arang limbah biomassa campuran kulit kopi dan tempurung kelapa dengan perekat tepung tapioka bisa menjadi alternatif sumber energi pembakaran yang baik.

\section{Analisis nilai kadar abu}

Nilai kadar abu menunjukkan berapa banyak bagian yang tersisa dari hasil pembakaran dalam hal ini adalah hasil pembakaran briket arang biomassa campuran kulit kopi dan tempurung kelapa dengan perekat tepung tapioka. Kandungan abu dalam sebuah briket arang akan menentukan kualitas dari briket arang tersebut. Semakin banyak kadar abu dalam briket arang maka akan menurunkan kualitas briket arang tersebut. Hal ini karena semakin tinggi kadar abu pada briket arang

114 Bagus Setyawan, Rosiana Ulfa - Analisis mutu briket arang dari limbah biomassa ... 
maka akan menurunkan nilai kalor dan kadar karbonnya (Anggoro et all, 2018). Data hasil analisis kadar abu pada briket arang limbah biomassa campuran kulit kopi dan tempurung kelapa dengan perekat tepung tapioka dapat dilihat pada Tabel 2.

Tabel 2. Hasil Analisis Kadar Abu pada Briket Arang Limbah Biomassa Campuran Kulit Kopi dan Tempurung Kelapa Dengan Perekat Tepung Tapioka

\begin{tabular}{|c|c|c|c|c|c|}
\hline \multirow{2}{*}{ Komposisi } & \multirow{2}{*}{ Kadar Abu } & \multicolumn{4}{|c|}{ Standar Baku Mutu } \\
\hline & & Jepang & Inggris & Amerika & SNI \\
\hline $\begin{array}{l}\mathrm{KK}: \mathrm{TK}=75 \%: 25 \% \\
\mathrm{KK}: \mathrm{TK}=25 \%: 75 \% \\
\mathrm{KK}: \mathrm{TK}=50 \%: 50 \%\end{array}$ & $\begin{array}{l}20,054 \% \\
20,862 \% \\
20,808 \%\end{array}$ & $3-6 \%$ & $5,9 \%$ & 8,3 \% & $8 \%$ \\
\hline
\end{tabular}

Berdasarkan Tabel 2 tentang analisis kadar abu pada briket arang biomassa campuran kulit kopi dan tempurung kelapa dengan perekat tepung tapioka dapat dilihat bahwa dari ketiga sampel rata-rata nilai kadar abunya adalah sekitar $20 \%$. Nilai kadar abu terendah terdapat pada campuran 75\% kulit kopi dan $25 \%$ tempurung kelapa. Nilai kadar abu tertinggi terdapat pada campuran tempurung kelapa $75 \%$ dan kulit kopi $25 \%$ sebesar 20,862\%. Hal ini menunjukkan bahwa kadar abu pada tempurung kelapa lebih besar dari kulit kopi, sehingga semakin banyak konsentrasi tempurung kelapa pada briket arang maka kadar abunya akan semakin tinggi. Hal ini dikarenakan waktu karbonasi antara kulit kopi dan tempurung kelapa yang tidak sama. Tempurung kelapa memiliki waktu karbonasi yang lebih lama dibandingkan kulit kopi dan juga temperatur pengarangan untuk tempurung kelapa lebih tinggi sehingga membuat kadar abunya juga lebih tinggi. Selain itu diduga tempurung kelapa memiliki kandungan silikat yang lebih tinggi dibandingkan dengan kulit kopi, dimana unsur silikat merupakan senyawa yang terkandung dalam kadar abu dan pengaruhnya kurang baik terhadap nilai kalor (Yuniarti et all, 2011). Berdasarkan analisis kadar abu ini menunjukkan bahwa faktor jenis bahan baku sangat mempengaruhi tinggi rendahnya kadar abu briket arang yang dihasilkan karena tiap bahan baku memiliki komposisi kimia dan jumlah partikel yang tidak sama dan mempengauhi jumlah abu yang dihasilkan (Ndraha, 2010). Secara umum kadar abu dari penelitian ini masih belum memenuhi standart mutu kadar abu baik dari Jepang, Inggris, Amerika, dan SNI. Hal ini diduga karena kurang sempurnanya proses karbonasi sehingga kualitas arang yang dihasilkan juga masih kurang baik, sehingga perlu ada penelitian lebih lanjut.

\section{Analisis laju pembakaran}

Analisis laju pembakaran dimaksudkan untuk mengetahui efektifitas suatu bahan bakar yang dalam hal ini adalah briket arang biomassa campuran kulit kopi dan tempurung kelapa dengan perekat tepung tapioka. Laju pembakaran berguna untuk mengetahui layak tidaknya briket ini untuk digunakan sebagai bahan bakar. Faktor-faktor yang mempengaruhi sifat pembakaran suatu bahan adalah tergantung pada ukuran partikelnya, kecepatan aliran udara, jenis bahan bakar, serta temperatur udara pembakarannya (Siahaan et all, 2013). Laju pembakaran briket ini didapatkan dengan membagi antara massa briket arang dengan lama waktu pembakaran briket arang tersebut sampai habis. Laju pembakaran briket arang limbah biomassa 
campuran kulit kopi dan tempurung kelapa dengan perekat tepung tapioka dapat dijelaskan pada Tabel 3.

Tabel 3. Hasil Analisis Laju Pembakaran pada Briket Arang Limbah Biomassa Campuran Kulit Kopi dan Tempurung Kelapa Dengan Perekat Tepung Tapioka

\begin{tabular}{ccccc}
\hline Komposisi & Massa Briket & Kerapatan Massa & $\begin{array}{c}\text { Lama } \\
\text { Pembakaran }\end{array}$ & $\begin{array}{c}\text { Laju } \\
\text { Pembakaran }\end{array}$ \\
\hline KK $: \mathrm{TK}=75 \%: 25 \%$ & $16,732 \mathrm{gr}$ & $0,6821 \mathrm{gr} / \mathrm{cm}^{3}$ & $4134,87 \mathrm{~s}$ & $0,0040 \mathrm{gr} / \mathrm{s}$ \\
$\mathrm{KK}: \mathrm{TK}=25 \%: 75 \%$ & $17,854 \mathrm{gr}$ & $0,7288 \mathrm{gr} / \mathrm{cm}^{3}$ & $4782,23 \mathrm{~s}$ & $0,0037 \mathrm{gr} / \mathrm{s}$ \\
$\mathrm{KK}: \mathrm{TK}=50 \%: 50 \%$ & $16,913 \mathrm{gr}$ & $0,6874 \mathrm{gr} / \mathrm{cm}^{3}$ & $4699,11 \mathrm{~s}$ & $0,0036 \mathrm{gr} / \mathrm{s}$ \\
\hline
\end{tabular}

Pada Tabel 3 dapat dilihat bahwa rata-rata laju pembakaran ketiga sampel briket arang tersebut adalah $\pm 0,003 \mathrm{gr} / \mathrm{s}$. Laju pembakaran briket arang ditentukan oleh massa briketnya dan lama pembakaran dari awal sampai briket habis, dan ditentukan juga oleh kerapatan massa briket arang tersebut. Semakin rapat massa briket maka massa briket akan semakin besar dan membutuhkan waktu yang lebih lama untuk habis dalam proses pembakarannya, sehingga laju pembakarannya pun juga akan lebih lama. Berdasarkan data pada Tabel 3 terlihat bahwa briket arang dengan komposisi kulit kopi yang lebih banyak kerapatan massanya akan lebih rendah $\left(75 \%\right.$ kulit kopi dengan kerapatan massa $\left.0,6821 \mathrm{gr} / \mathrm{cm}^{3}\right)$ daripada briket arang dengan komposisi tempurung kelapa yang lebih banyak akan memiliki kerapatan yang lebih tinggi (75\% tempurung kelapa dengan kerapatan massa 0,7288 $\mathrm{gr} / \mathrm{cm}^{3}$ ), sedangkan briket arang dengan campuran 50\% kulit kopi dan 50\% tempurung kelapa memiliki kerapatan massa $0,6874 \mathrm{gr} / \mathrm{cm}^{3}$. Berdasarkan data laju pembakaran dapat dilihat bahwa semakin rendah kerapatan massa maka laju pembakaran akan semakin cepat, yakni komposisi $75 \%$ kulit kopi dengan kerapatan $0,6821 \mathrm{gr} / \mathrm{cm}^{3}$ memiliki laju pembakaran $0,004 \mathrm{gr} / \mathrm{s}$. Hal ini karena senyawa volatile kulit kopi lebih tinggi daripada tempurung kelapa. Hal ini seuai dengan pernyataan berikut bahwa bahan yang memiliki kadar volatil tinggi maka briket akan mudah terbakar dengan kecepatan pembakaran tinggi (Jamilatun, 2008).

\section{Analisis nilai kalor}

Salah satu parameter kualitas briket arang yang terpenting adalah nilai kalor, karena nilai kalor sangat menentukan kualitas briket arang. Semakin tinggi nilai kalor pada briket arang maka semakin baik juga kualitas briket arang tersebut sehingga layak untuk menjadi bahan bakar alternatif. Tinggi rendahnya nilai kalor juga dipengaruhi oleh kadar air dan kadar abu yang terkandung di dalam briket arang tersebut. Umumnya semakin tinggi kadar abu dan kadar airnya maka nilai kalor briket arang akan semakin menurun, dan sebaliknya. Pengujian nilai kalor pada briket arang limbah biomassa campuran kulit kopi dan tempurung kelapa dengan perekat tepung tapioka ini menggunakan bomb kalorimeter yang tujuannya adalah mengetahui besar energi bruto yang terdapat pada briket arang campuran kulit kopi dan tempurung kelapa ini. Hasil uji nilai kalor briket arang limbah biomassa campuran kulit kopi dan tempurung kelapa dengan perekat tapioka dapat dijelaskan pada Tabel 4. 
Tabel 4. Hasil Analisis Nilai Kalor pada Briket Arang Limbah Biomassa Campuran Kulit Kopi dan Tempurung Kelapa Dengan Perekat Tepung Tapioka

\begin{tabular}{ccccc}
\hline Komposisi & Kadar Air & Kadar Abu & Nilai Kalor & Standar SNI \\
\hline KK $:$ TK $=75 \%: 25 \%$ & $13,872 \%$ & $20,054 \%$ & $6152,4 \mathrm{kal} / \mathrm{gr}$ & \\
KK $:$ TK $=25 \%: 75 \%$ & $14,966 \%$ & $20,862 \%$ & $3047,6 \mathrm{kal} / \mathrm{gr}$ & $5000 \mathrm{kal} / \mathrm{gr}$ \\
$\mathrm{KK}: \mathrm{TK}=50 \%: 50 \%$ & $12,487 \%$ & $20,808 \%$ & $4869,2 \mathrm{kal} / \mathrm{gr}$ & \\
\hline
\end{tabular}

Berdasarkan Tabel 4 diatas dapat dilihat bahwa sesuai dengan teori nilai kalor dipengaruhi oleh kadar air dan kadar abunya. Nilai kalor terendah terdapat pada briket arang dengan konsentrasi tempurung kelapa $75 \%$ dengan nilai kalornya sebesar $3047,6 \mathrm{kal} / \mathrm{gr}$. Nilai kalor ini yang paling rendah karena pada briket arang dengan $75 \%$ tempurung kelapa ini memiliki kadar air dan kadar abu yang paling tinggi yakni sebesar $14,966 \%$ dan 20,862\%. Sedangkan nilai kalor tertinggi terdapat pada briket arang dengan konsentrasi kulit kopi sebesar $75 \%$ dengan nilai kalor $6152,4 \mathrm{kal} / \mathrm{gr}$. Hal ini juga karena pada briket arang ini memiliki kadar air dan kadar abu yang paling rendah yaitu masing-masing sebesar 13,872\% dan 20,054\%. Perbedaan nilai kalor selain karena dipengaruhi oleh kadar air dan kadar abu juga karena bahan bakunya. Kulit kopi memiliki nilai kalor yang lebih tinggi dibandingkan dengan tempurung kelapa sehingga ketika dijadikan briket arang maka briket dengan konsentrasi kulit kopi yang tinggi akan menghasilkan nilai kalor yang tinggi juga. Nilai kalor yang tinggi akan membuat briket ini lebih efisien dan dapat menghemat kebutuhan briket yang digunakan. Tabel 4 menunjukkan bahwa briket arang dengan konsentrasi kulit kopi $75 \%$ ini nilai kalornya sudah sesuai dengan SNI bahkan nilainya diatas SNI yakni 6152,4 kal/gr melebihi standar SNI sebesar $5000 \mathrm{kal} / \mathrm{gr}$. Nilai kalor briket arang ini bahkan sudah sesuai dengan standar Jepang yakni berkisar antara 6000-7000 kal/gr dan sudah hampir sesuai juga dengan standar Amerika yakni $6230 \mathrm{kal} / \mathrm{gr}$. Hasil ini membuktikan bahwa briket arang biomassa campuran kulit kopi dan tempurung kelapa dengan perekat tepung tapioka ini memiliki kualitas yang sangat baik dan bisa menjadi alternatif sumber energi bakar yang baru.

Terdapat beberapa penelitian sebelumnya yang membahas tentang uji kualitas briket arang tetapi dengan bahan limbah biomassa yang lain. Hasil penelitian Lestari et all (2010), menyimpulkan bahwa briket arang dengan bahan tongkol jagung memiliki kadar air sekitar 2,5\% - 4,8\%, kadar abu 6,6\%-11,35\%, dengan berat briket rata-rata 4 gram. Nilai kalor per unit massa briket berkisar antara 3870,25 - 5484,54 kkal/kg untuk perekat kanji dan 5064,17 - 5196,83 kkal/kg untuk perekat tepung sagu. Penelitian Rumiyanti et all (2018), dengan menganalisis kualitas briket dari beberapa limbah biomassa yakni sekam padi, ampas tebu, kulit singkong, tongkol jagung, dan batok kelapa menunjukkan bahwa kualitas briket arang terbaik adalah kulit singkong karena memiliki kadar air dan abu terendah, yaitu $0,3833 \%$ dan $0,8452 \%$. Sementara, kualitas briket arang terburuk adalah tongkol jagung karena memiliki kadar air tertinggi yaitu 2,412 \% dan karbon tertambat terendah yaitu 71,442 $\%$. Dibandingkan beberapa penelitian serupa hasil dari penelitian ini memang masih belum optimal karena masih ada beberapa faktor yang harus diperbaiki seperti kualitas pengarangan dan juga komposisi perekatnya. Akan tetapi penelitian ini memiliki keunggulan yakni bahan yang dipakai adalah limbah kulit kopi dan 
tempurung kelapa yang memiliki potensi bagus untuk dimanfatkan menjadi briket arang. Ditambah lagi kopi dan kelapa merupakan salah satu komoditas unggulan di Banyuwangi sehingga briket arang yang dihasilkan dari campuran kedua bahan tersebut akan menjadi briket arang dengan kearifan lokal Banyuwangi dan bisa menjadi sumber usaha baru bagi masyarakat Banyuwangi khususnya.

\section{SIMPULAN DAN SARAN}

Hasil penelitian menunjukkan bahwa kadar air dan kadar abu briket arang ini masih dibawah standart mutu briket arang internasional dan SNI. Hal ini diduga karena proses karbonasi arang yang kurang maksimal. Akan tetapi, nilai kalor briket arang hasil penelitian ini di atas standart mutu briket arang SNI. Perlu dilakukan penelitian lebih lanjut tentang pengaruh waktu, temperatur karbonasi, komposisi perekat terhadap kualitas briket arang yang dihasilkan.

\section{UCAPAN TERIMA KASIH}

Ucapan terima kasih yang sebesar-besarnya disampaikan kepada Direktorat Riset dan Pengabdian Masyarakat Direktorat Jenderal Penguatan Riset dan Pengembangan Kementerian Riset, Teknologi, dan Pendidikan Tinggi Republik Indonesia yang telah memberikan dana hibah penelitian sehingga penelitian ini dapat terlaksana dengan baik.

\section{RUJUKAN}

Anggoro, D. D., Wibawa, M. H. D., \& Fathoni, M. Z. (2018). Pembuatan Briket Arang Dari Campuran Tempurung Kelapa dan Serbuk Gergaji Kayu Sengon. Teknik, 38(2), 76. https://doi.org/10.14710/teknik.v38i2.13985

Almu, M,. Syahrul, S., \& Padang, Y. (2014). Analisa Nilai Kalor Dan Laju Pembakaran Pada Briket Campuran Biji Nyamplung (Calophyllm Inophyllum) Dan Abu Sekam Padi. Dinamika Teknik Mesin, 4(2), 117-122. https://doi.org/10.29303/d.v4i2.61

Arni, Labania, H. M., \& Nismayanti, A. (2014). Studi Uji Karakteristik Fisis Briket Bioarang sebagai Sumber Energi Alternatif. Online Jurnal of Natural Science, 3(March), 89-98. Retrieved from http://jurnal.untad.ac.id/jurnal/index.php/ ejurnalfmipa/article/view/2213

BPS. (2018). Provinsi Jawa Timur Dalam Angka 2018. BPS Provinsi Jawa Timur, 390. Retrieved from https://jatim.bps.go.id/

Eka Putri, R., \& Andasuryani, A. (2017). Studi Mutu Briket Arang Dengan Bahan Baku Limbah Biomassa. Jurnal Teknologi Pertanian Andalas, 21(2), 143. https://doi.org/10.25077/jtpa.21.2.143-151.2017

Fairus, S., Rahman, L., \& Apriani, E. (2011). Pemanfaatan Sampah Organik Secara Padu Menjadi Alternatif Energi: Biogas dan Precursor Briket. Prosiding Seminar Nasional Teknik Kimia'Kejuangan' Pengembangan Teknologi Kimia Untuk Pengelolaan Sumber Alam Manusia, (2006), E01. Retrieved from http://repository.upnyk.ac.id/343/1/Pemanfaatan_Sampah_Organik_Secara_Pa du.pdf

Faizal, M., Andynapratiwi, I., \& Putri, P. D. A. (2014). Pengaruh Komposisi Arang Dan Perekat Terhadap Kualitas Biobriket Dari Kayu Karet. Jurnal Teknik Kimia, 20(2), 36-44. Retrieved from http://jtk.unsri.ac.id/index.php/jtk/article/view $1170 / 169$ 
Gustan Pari, M. \& J. (2012). Teknologi Pembuatan Arang, Briket Arang Dan Arang Aktif Serta Pemanfaatannya. Gelar Teknologi Tepat Guna. Retrieved from http://www.forda-mof.org/files/arang-Gustam.pdf

Gustan Pari dan Sasa Abdurrohim. (2003). Pembuatan Arang Aktif Dari Tempurung Kelapa Sawit Dan Serbuk Kayu Gergajian Campuran. Jurnal Penelitian Hasil Hutan. Retrieved from http://ejournal.forda-mof.org/ejournal-litbang/index.php/ $\mathrm{JPHH} /$ article/view/4041/3544

Hendra, D. (2006). Pembuatan Arang Aktif Dari Tempurung Kelapa Sawit Dan Serbuk Kayu Gergajian Campuran. Jurnal Penelitian Hasil Hutan, 24(2), 117132. Retrieved from http://ejournal.forda-mof.org/ejournal-litbang/index.php/ $\mathrm{JPHH} /$ article/view/4041/3544

Iriani, Carnella, C., \& Sari, C. (2016). Pembuatan biobriket dari pelepah dan cangkang kelapa sawit : pengaruh variasi komposisi bahan baku dan waktu karbonisasi terhadap kualitas briket. Jurnal Teknik Kimia, 5(3), 31-37. Retrieved from https://jurnal.usu.ac.id/index.php/jtk/article/download/14753/6443

Jamilatun, S. (2008). Sifat-sifat penyalaan dan pembakaran briket biomassa, briket batubara dan arang kayu (in Bahasa). Jurnal Rekayasa Proses, 2(2), 37-40. Retrieved from https://jurnal.ugm.ac.id/jrekpros/article/view/554

Jahiding, M., Mashuni, Hasan, E.S,. \& Gangganora, S,A,. (2014). Pengaruh Jenis Dan Perekat Terhadap Kualitas Briket Batubara Muda. Jurnal Aplikasi Fisika, 10(2), 67-77. Retrieved from http://ojs.uho.ac.id/index.php/JAF/article/view/1498

Lestari Aripin, Yanti, Zainudin, Sukmawati, Marliani, L. (2010). Analisis Kualitas Briket Arang Tongkol Jagung Yang Menggunakan Bahan Perekat Sagu Dan Kanji. Jurnal Aplikasi Fisika, 6(2), 93-96. Retrieved from http://jaf-unhalu.webs. com/5_JAF-agustus_10_(Lina_Lestari,_Aripin).pdf

Maryono, Sudding, \& Rahmawati. (2013). Pembuatan dan Analisis Mutu Briket Arang Tempurung Kelapa Ditinjau dari Kadar Kanji. Jurnal Chemica, 14(1), 74-83. Retrieved from http://ojs.unm.ac.id/index.php/chemica/article/view/795

Masthura, M. (2019). Analisis Fisis Dan Laju Pembakaran Briket Bioarang Dari Pelepah Daun Pisang. Jurnal Elkawnie, 5(1), 58-65. Retrieved from https://www. doi.org/\%2010.22373/ekw.v5i1.3621

Nodali, N. (2010). Uji Komposisi Bahan Pembuat Briket Bioarang Tempurung Kelapa Dan Serbuk Kayu Terhadap Mutu Yang Dihasilkan, 2010. Retrieved from http://repository.usu.ac.id/handle/123456789/7528

Patandung, P. (2017). Pengaruh Jumlah Tepung Kanji Pada Pembuatan Briket Arang Tempurung Pala. Jurnal Penelitian Teknologi Industri, 6(2), 95-102. Retrieved from http://ejournal.kemenperin.go.id/jpti/article/view/3195

Potensi Sektor Pertanian Sebagai Penghasil dan Pengguna Energi Terbarukan. (2015). Perspektif, 6(2), 85-93. https://doi.org/10.21082/p.v6n2.2007

Prastowo, B. (2007). Potensi Sektor Pertanian Sebagai Penghasil dan Pengguna Energi Terbarukan. Jurnal Perspektif, 6(2), 84-92. Retrieved from http://ejurnal.litbang.pertanian.go.id/index.php/psp/article/viewFile/2862/2489

Qistina, I., Sukandar, D., \& Trilaksono, T. (2016). Kajian Kualitas Briket Biomassa dari Sekam Padi dan Tempurung Kelapa. Jurnal Kimia VALENSI, 2(2), 136-142. https://doi.org/10.15408/jkv.v2i2.404

Rindayatno, R., \& Lewar, D. O. (2017). Kualitas Briket Arang Berdasarkan Komposisi Campuran Arang Kayu Ulin (Eusideroxylon zwageri Teijsm \& Binn) Dan Kayu Sengon (Paraserianthes falcataria). ULIN: Jurnal Hutan Tropis, 1(1). https://doi.org/10.32522/u-jht.v1i1.792

Rumiyanti, L., Irnanda, A., \& Hendronursito, Y. (2018). Analisis Proksimat Pada Briket Arang Limbah Pertanian. Spektra: Jurnal Fisika Dan Aplikasinya, 3(1), 15- 
22. https://doi.org/10.21009/spektra.031.03

Sariadi, S. (2016). Pemanfaatan Kulit Kopi Menjadi Biobriket. Jurnal Sains Dan Teknologi Reaksi, 7(1), 16-25. https://doi.org/10.30811/jstr.v7i1.104

Siahaan, S., Hutapea, M., \& Hasibuan, R. (2013). Penentuan Kondisi optimum Suhu Dan Waktu Karbonisasi Pada Pembuatan Arang Dari Sekam Padi. Jurnal Teknik Kimia USU, 2(1). Retrieved from https://jurnal.usu.ac.id/index.php/jtk/article /view/1324

Widarti, E. Sarwono, \& Hartono, R. (2004). Studi Eksperimental Karakteristik Briket Organik dengan Bahan Baku dari PPLH Seloliman. Jurnal Teknik Fisika FTI ITS Surabaya, 1-10. Retrieved from http://digilib.its.ac.id/public/TS-Undergraduate12999-Paper.pdf

Yuniarti, Theo, Y. P., Faizal, Y., \& Arhamsyah. (2011). Briket Arang Dari Serbuk Gergajian Kayu Meranti Dan Arang Kayu Galam. Jurnal Riset Industri Hasil Hutan, 3(2), 38-43. Retrieved from http://ejournal.kemenperin.go.id/jrihh /article/view/1194 